\title{
8 \\ Sessional Teaching Staff and Learning, Teaching, and Assessment: Engaging the Marginalised
}

\author{
Sally Ann Bradley \\ Sheffield Hallam University, UK
}

This paper discusses the issues around the professional development needs of sessional teaching staff in the UK. The introduction of the UK professional standards framework for teaching and supporting learning in higher education in 2006 raised the issue of engaging the wide range of staff, faculty, and learning support in professional development. Sessional teaching staff present a challenge when their main employment is outside of the institution.

\section{Introduction}

$\mathrm{T}$

he debate surrounding employment and support for sessional teachers, part-time faculty, or associate lecturers, has been around for many years (Abbas \& McLean, 2001; Tait, 2002; Knight, 2002). Within the UK higher education sector, there are at least 50,000 sessional teaching staff currently employed, with a high proportion in disciplines such as art and design (Bryson, Kenny, Morris, \& Price, 2007). The Part-Time Teachers initiative was started in 2001, through the Learning and Teaching Support Network, and revived by the Higher Education Academy (HEA), in 2005 with the establishment of a part-time teachers' network (Higher Education Academy, 2006a).

The challenges facing the professional development of this group of faculty is universal. It was estimated that $40 \%$ of instruction in the United
States, was being delivered by adjunct faculty members (Wickun \& Stanley, 2002). In Australia, the National Tertiary Education Union claimed that in 2000 the equivalent of $15.4 \%$ of full-time faculty were employed as casual, sessional teaching staff. Sheffield Hallam University is a "Post 1992" university with approximately 28,000 students and 1,100 full- and part-time faculty, supported by approximately 1000 sessional contracts delivered by 232 sessional teachers.

\section{The Context}

Sessional teachers come from a range of backgrounds with different professional and teaching experience (Bryson, 2006): 
- full time professionals outside the institution e.g. accountants, National Health Service professionals;

- portfolio workers, e.g. teachers within more than one higher education institution or further education college;

- freelance/consultants, e.g. artists and designers;

- part time professionals, e.g. journalists;

- sole employment as associate lecturer;

- retired faculty;

- graduate teaching assistants; and

- technicians.

Within the context of this study, sessional staff are defined as those who have a larger teaching role than a guest speaker or visiting lecturer but do not have a fractional contract (i.e. 0.5 full time).

This raises the question: "How do you communicate learning, teaching and assessment developments and institutional processes to this hard to reach and transient group?"

\section{Methodology}

The research examined the international and national context, drawing on the Dearn Report (2002) and the public exposition of the institutional commitment to professional development. In the UK, the publication of the sector standards for teaching and learning in higher education (Higher Education Academy, 2006b) also raised the profile of continuing professional development for all higher education teaching staff, which includes sessional teachers.

The Staff and Educational Developers Association (SEDA) JISC email list was used, alongside contacts through the International Consortium of Educational Developers (ICED), to identify different modes of delivery for sessional teaching staff development. A workshop during the SEDA Educational Developers conference was used to identify the needs of sessional teaching staff from a developers' perspective (Bradley \& Beckingham, 2006). An internal Learning, Teaching, and Assessment (LTA) conference was used to identify needs from line managers, academics in LTA roles, together with library and student services support staff.

A pilot questionnaire was developed and administered through an LTA mid-year conference. Of the 90 sessional teaching staff involved, 28 returned the postal questionnaire. The mail shot questionnaire (see Appendix) was then sent to all sessional teaching staff holding current contracts. Of the 232 questionnaires sent out, $42 \%$ were returned within two weeks.

\section{Findings}

\section{Institutional support}

Most Higher Education institutions offer courses for sessional teaching staff and graduate teaching assistants - some accredited at master's level, others certificated with or without academic credit. In other cases, sessional teaching staff were supervised on the flexible learning module by faculty in LTA roles. However, because of the nature of sessional employment, a regular timetabled course is not convenient for all staff.

There were three distinct stages in the development cycle for sessional teachers: pre teaching, early teaching, and established teaching - each stage requiring different levels of information and guidance. All aspects of teaching and learning were seen as important by all groups of staff, together with expectations of what, why, and how something should be taught. Understanding the composition of the student cohort was also important, for example, having access to student profiles and their prior learning experience. Other information such as course definitive documents, module handbooks, and university regulations including academic integrity were also seen as essential documents. Line managers and learning support staff (e.g. librarians, student services staff) focused on the operational aspects and administrative functions when commencing teaching. Educational developers focused on the module: learning outcomes, course descriptions, teaching, and learning issues during the early stages of teaching.

When teaching has commenced, the infor- 
mation needed to support sessional teaching staff still include some administrative functions such as induction, timetabling, finance, student support, and technical support. The following learning and teaching aspects also increases:

- learning contracts for disabled students;

- attendance monitoring policies;

- course information;

- assessment - marking and feedback;

- use of the virtual learning environment (VLE);

- resources to improve practice;

- university regulations;

- personal support for the member of staff; and

- development opportunities.

Educational developers thought that getting feedback from course teams, and review of learning and teaching were also important at this stage. The longer term needs of sessional teachers included:

- assessment;

- guides to good practice;

- plagiarism;

- personal development planning;

- e-learning; and

- university-led initiatives like widening participation, ethics and enterprise.

Educational developers suggested a deeper understanding of pedagogies and a theoretical underpinning of different practices in learning and teaching, such as problem-based learning within the subject discipline, is required.

The sessional teaching staff were asked about their specific needs: 46 related to their development and 24 related to university processes. They requested this information be communicated through induction packs sent out with their initial contact, and where possible, sent before start of teaching, or through face-to-face delivery. This correlates with the data collected from the line managers and support staff. Specific development needs expressed, related to VLE training, closely followed by teaching skills. The findings from the sessional teachers emphasizes the importance of professional development to this group.

\section{Barriers to Engagement with Development}

Engagement in any professional development can be damaged if institutional procedures such as the payment for contracts or the timeliness of payment are ignored. Inconsistency between different contracts within the same institution exacerbates this issue further; for example, some sessional contracts include additional time for marking, and for other contracts, marking is included in the allocated contact time. This fosters the notion of exploitation of this group of staff, where goodwill does not pay the mortgage. Of course, this may not be an issue if sessional teaching supplements other earnings, but for many it is their sole source of income.

Recognition and the feeling of "being valued" also rates highly when asking for commitment to professional development. Sessional teachers are often isolated, teaching outside of the normal Monday to Friday 9-5 context, thus reducing contact with their subject group and discipline staff. How do they benchmark their teaching? Being an integrated member of a course team and subject group is an essential part of the development of the sessional teacher.

\section{The Way Forward}

As we adopt different teaching approaches to cater for diverse student cohorts, through distance or blended learning in addition to face-to-face delivery, we should also provide flexible development opportunities to meet sessional teaching staff needs. Sessional teaching staff want to deliver good quality teaching and learning experiences. However, without access to information and feedback on current learning, teaching, and assessment practice, it is easy for this group to remain within their comfort zone. As one associate lecturer said, "stay safe and do what you 
are familiar with.”

There is a need for an induction process for all new sessional teachers, which includes different role expectations between full time and sessional teachers, to establish a common understanding between line managers/course leaders and the sessional teacher. This should cover the administrative elements such as:

- identity cards;

- computer logins;

- email addresses;

- access codes; and

- key contacts - library and student services and available support.

We should not assume that a sessional teacher understands the support functions available within our own institution; culture and local practice is unique to each higher education institution. Assessment processes and procedures are another early requirement:

- key dates - examinations and exam boards;

- turnaround time for feedback;

- feedback procedures;

- policies relating to extenuating circumstances; and

- plagiarism.

Issues around assessment criteria also need to be addressed, such as a clear understanding of the different academic levels and criteria for marking different activities. The sessional teacher may not be familiar with the assessment of group presentations, annotated bibliographies, videos, etc. Other areas to be addressed include second marking, adaptations required for disabled students, moderation, and the role of the exam board at an appropriate time.

Capturing and sharing good support practice for sessional teaching support is the next stage of this project. Pockets of good practice have already been identified through the questionnaire, and progress made. In 2005, a newsletter was developed for sessional teachers, "LTA Matters." A mid-year LTA conference was organised to allow sessional teachers to meet other part-time and recently appointed faculty, along with members of full-time faculty with LTA roles within the faculty. The conference took the form of a faculty induction, with sessional teachers funded to attend by the central Educational Development Unit. The conference included sessions from the library, student services as well as the Learning and Teaching Institute. Based on the conference feedback, a VLE site was set up specifically for sessional teachers as a key reference point for information, and learning and teaching materials relevant to the faculty. For sessional teaching staff who choose, appraisals have been instigated within the subject groups, providing an opportunity to discuss work and development needs.

One of the identified development needs related to creating and maintaining VLE sites and a resource pack has now been created. This has been distributed to all teaching faculty members, with assurances that sessional teachers also received a copy. A university-wide LTA orientation event is also being developed with a view to including all new academic staff in an induction specifically relating to LTA; this will also include new sessional teachers. The aim of the LTA orientation event is to share with new staff the ethos of LTA at the institution, what makes LTA special, learner focused teaching and learning, the diversity of the student groups, and entry qualifications of our students. A pilot distance learning short course leading to Higher Education Academy registration has also been established with a view to co-teaching with subject discipline faculty and academics in the Educational Development Unit.

\section{Conclusion}

As an institution we are reliant on sessional teachers but the integration and support could be better and more consistent. The two quotes below demonstrate the inconsistency of support within the institution:

I enjoy being an Associate Lecturer but I do feel marginalised as my contract is limited. I tend to teach or be available for students at weekends and evenings there- 
fore there isn't a community of practice. I've been very impressed with the support, guidance and help I've received, and how my input is valued. This is mainly down to the people in my dept. I have taught at Sheffield University too and never had the kind of support I receive at Hallam.

- Quotes from questionnaire

There is one group of sessional teachers which has not been consulted because of the difficulty in identification. These are members of staff, who do not hold academic posts but deliver sessional teaching. They do not receive the same rights of a sessional teacher and even less support and development. These are the marginalised of the marginalised!

\section{References}

Abbas, A. \& McLean, M. (2001). Becoming sociologists: Professional identity for part-time teachers of university sociology. British Journal of Sociology of Education, 22(3), 339-352.

Bradley, S.A. \& Beckingham, S. (2006). Staff and Educational Development Association Developers Conference: Associate lecturers and learning, teaching and assessment: Forgotten few or missing many. Birmingham, UK: Novotel.

Bryson, C. (2006). Distinguishing categories of parttime teachers. Retrieved May 12, 2007, from http://www.heacademy.ac.uk/5180.htm

Bryson, C., Kenny, L., Morris, A., \& Price, P. (2007). Staff and Educational Developers Association Spring Conference: Enhancing the support and development of part-time teachers: Learning from examples of good practice. Glasgow: Marriott Hotel.

Dearn, J., Fraser, K., \& Ryan, Y. (2002). Professional development for university teaching in Australia. Retrieved August 14, 2007, from http://www. dest.gov.au/sectors/higher_education/publications_resources/other_publications/professional_development_for_university_teaching.htm

Higher Education Academy. (2006a). Part-time teachers' HE network: Briefing note, Higher Education Academy. Retrieved August 14, 2007, from http://www.heacademy.ac.uk/ourwork/ professional/parttime

Higher Education Academy. (2006b). UK professional standards framework for teaching and supporting learning in Higher Education. Retrieved April 5, 2008, from http://www.heacademy. ac.uk/assets/York/documents/ourwork/professional/ProfessionalStandardsFramework. pdf

Knight, P. (2002). Being a teacher in higher education. Buckingham, UK: SRHE and Open University Press.

Tait, J. (2002). From competence to excellence: A systems view of staff development for parttime tutors at-a-distance. Open Learning, $17(1), 69-82$.

Wickun, W. G. \& Stanley, R. E. (2002). The Role of adjunct faculty in higher education. Retrieved August 14, 2007, from http://mtprof.msun. edu/Win2000/Wickun.html 


\section{Appendix}

\section{Associate Lecturer Questionnaire}

We are undertaking a project to identify the development needs of Associate Lecturers. And would be grateful if you would spend a few minutes telling us about your experience at SHU, what information or support you were given and would be useful in your Associate Lecturer career. The results of the questionnaire will be anonymous but will feed into the Associate Lecturer Professional Development project.

Approximately how many years have you had an Associate Lecturer contact? How many contracted hours do you have for the academic year $2006-2007$ ?

$$
0-29 \quad 30-60 \quad 60 \text { plus }
$$

How many modules do you contribute to?

Do you work for SHU in another capacity?

Optional:

Faculty/ies
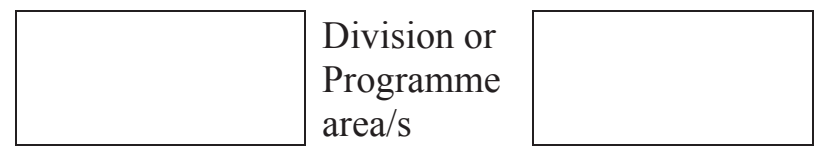

Subject group/s

What information were you given, or provided with web links, when you first started, please tick relevant columns?

\begin{tabular}{|l|l|l|l|l|}
\hline & Received & Awareness & Used & $\begin{array}{l}\text { Found } \\
\text { useful }\end{array}$ \\
\hline $\begin{array}{l}\text { Claim/payment } \\
\text { information }\end{array}$ & & & & \\
\hline $\begin{array}{l}\text { SHU Card (Learning } \\
\text { Centre/ ID/ Access) }\end{array}$ & & & & \\
\hline PC login code & & & & \\
\hline SHU email address & & & & \\
\hline $\begin{array}{l}\text { Contact details of course } \\
\text { leader, Administrator etc }\end{array}$ & & & & \\
\hline $\begin{array}{l}\text { Details of where to collect } \\
\text { post }\end{array}$ & & & & \\
\hline Induction to SHU & & & & \\
\hline Fire awareness training & & & & \\
\hline Details of access to pc & & & & \\
\hline $\begin{array}{l}\text { Details of access to a } \\
\text { photocopier }\end{array}$ & & & & \\
\hline Course handbook & & & & \\
\hline Module register & & & & \\
\hline $\begin{array}{l}\text { Quality and University } \\
\text { guidelines }\end{array}$ & & & & \\
\hline $\begin{array}{l}\text { Associate Lecturer } \\
\text { handbook }\end{array}$ & & & & \\
\hline Induction to Blackboard & & & & \\
\hline $\begin{array}{l}\text { Blackboard (VLE) basics } \\
\text { guide }\end{array}$ & & & & \\
\hline Attended a Learning & & & & \\
\hline
\end{tabular}




\begin{tabular}{|l|l|l|l|l|}
\hline Centre Induction & & & & \\
\hline $\begin{array}{l}\text { Legislation about disabled } \\
\text { students and equal } \\
\text { opportunities }\end{array}$ & & & & \\
\hline Other: & & & & \\
\hline & & & & \\
\hline & & & & \\
\hline & & & & \\
\hline & & & & \\
\hline
\end{tabular}

What information/activity would support your needs as an Associate Lecturer now and how should this be supported or communicated?

\begin{tabular}{|l|l|l|}
\hline Needs & Support & Communicated \\
\hline & & \\
& & \\
& & \\
\hline
\end{tabular}

What are the three most important issues/concerns you have as Associate Lecturer?

Any other comments about being an Associate Lecturer at Sheffield Hallam University:

Please give your contact details if you would like to chat, face to face or over the telephone, about your experience or if you would like to find out more about the project.

Name:

Email:

Telephone number and best time to contact:

Please return this to Sally Bradley, Sheffield Hallam University, Learning and Teaching Institute, Level 7 Adsetts Centre, Howard Street, Sheffield S1 1WB or use the pre paid envelope provided.

Alternatively contact Sally Bradley on s.a.bradley@shu.ac.uk

Many thanks for taking the time to complete this questionnaire. 